\title{
Effects of Migration Flows on Local Labor Market: A Regional Implementation on Turkey
}

\author{
Asst. Prof. Dr. Atakan Durmaz (Bayburt University, Turkey) \\ Prof. Dr. Adem Kalça (Karadeniz Technical University, Turkey)
}

\begin{abstract}
Migration flows are an important research topic in the economic literature due to the economic effects they have on both the homeland and the countries receiving the immigration. Studies on homeland focus on issues such as remittances, foreign direct investment, Technology and knowledge transfers and trade links, while studies on immigrant countries focus on issues such as immigrants' impacts on the local labor market and commercial effects. The aim of this study starting from this point is the recent massive migration flows exposed to these migration flows in Turkey to determine their impact on the local labor market. In the study, the data set covering the period of 2011-2016 was used for 26 sub-regions of Turkey and this was tested using panel data analysis. According to the results, while immigrants with a work permit in Turkey have a statistically significant and positive impact on the women's labor force participation rate and the total labor force participation rate, there is no statistically significant effect on male labor force participation rates. In other words, according to the results, immigrants with a work permit in Turkey are complementary in terms of local labor force.
\end{abstract}

\section{Introduction}

Immigration has become one of the most important topics of popular debate in the social science literature (especially economics). One of the most important questions about immigration concerns is the beneficial and harmful effects of immigrants on the immigration country economies. At this point, immigration is thought to have negative effects on the labor market at least in the short term. Unfavorable effects of migration on local workers' employment opportunities and wages are one of the main concerns in the not true and that immigrants have many positive effects on the local labor market.

Some of the earliest studies on this subject assume that this migrant population is a different production factor. In other words, the labor factor is composed of immigrants and local people, and immigrants and local people are thought to be irreplaceable (Grossman 1982). However, such a distinction is difficult to make. As a matter of fact, subsequent studies have focused on a skillful distinction between different groups of labor inputs. Altonji and Card (1991); Dustmann et. al. (2005) how the skills are described in detail depends on the work, but the typical dimensions are education attainment, Card (2001) occupation, or Borjas (2003) experience and education. More recently, some articles (Ottaviano and Peri 2006; Manacorda, Manning and Wadsworth 2006) have taken further steps and relied on the excellent substitutability assumption of immigrants and local peoples in the predefined skill categories using nested production technologies.

The theory of economy is very suitable for helping to understand the possible consequences of migration for receiving countries, and the theoretical aspects of the possible effects on the labor market of the receiving countries are well understood. However, it is not wrong to say that the theorem's estimates are clearly cut off. It is in line with the economic models that some local workers who change the size or composition of the workforce resulting from migration can harm the labor market; However, similar to the theory, the shift in skills of the workforce is also compatible with the fact that migration does not have any effect on the wages and employment of local workers, at least in the long run. Economic models foresee that the effects of immigration on the labor market depend on the nature of the receiving country's economy and on the skill mix of immigrants compared to the local labor force (Dustmann et. al., 2008).

This statement shows that the various possible outputs comply with economic theory. Migration can reduce wages and employment of indigenous people. Nevertheless, it is not at all consistent with economic theory to think that long run responses to migration have no effect or that immigration increases the wages of migrant labor supplement workers. In the case of long-term effects, however, it is important that the economy is open to trade and the flexibility of harmonizing the economy with the output mix produced outside of wages. The impact of migration on the labor market is not limited to wages alone. At the same time, new job opportunities created in the labor market are another factor to be addressed at this point. Although immigrants have a good reason to enter the labor market and rival the local workforce for their current job opportunities, in some cases they have shown new opportunities for the local workforce by creating new employment opportunities.

\section{A Review of the Literature}

Although the impact of migration on the local labor market is often one of the topics discussed in the literature, there is no consensus on the impact of migration. For example, Altonji and Card (1991), Card (2001), Dustmann et al. (2005) and Dustman et al. (2008) argued that the labor force flows had little effect on the wages of the local 
labor force; Borjas (2003) found that the labor flows are a significant negative impact on the wages of the local labor force. In studies such as Mishra (2007) and Kifle (2009), it has been found that migration flows have significant positive effects on the wages of the local labor force. Studies in the literature have also shown that migration has different effects on the local labor market. The direction of the impacts depends on a number of factors: the substitution possibilities between immigrants and local labor force, and the contribution of immigration to total supply and demand.

The higher the rate of substitution between immigrants and the local labor force, the worse the wages of the local labor force will be (Borjas 2003; Orrenius and Zavodny 2007). The level of decline in wages depends on the degree of substitution and is the most severe when there are excellent displaced persons of immigrants and natives. In addition, if there is a complementary relationship between immigrants and local labor force, there may be positive changes in macroeconomic gains from migration (Ottaviano and Peri 2007; Borjas et. al. 2008). A complementary relationship increases the marginal productivity of labor in the economy and leads to positive economic results for the workforce.

It should be noted that the flexibility of substitution of the migrant workforce is not the same in the whole labor market. The power of substitution between immigrants and pre-existing labor force varies depending on some factors (Orrenius and Zavodny 2007; Dustman et. al. 2008). Among these factors, the need for skill is unique to different industries. In sectors that require less skill, immigrants and pre-existing workers are more likely to be substituted. However, it is more difficult for immigrant and local workers to substitute for each other in the industry, which requires substantial technical skills and technical knowledge. Such industries are often sectors with a high degree of local language skill and dominance of the local labor market. Another important factor at the same time is the aggregate supply and demand change caused by migration movements. Migration flows increase labor supply in the local labor market, which leads to increased production in the economy. However, the fact that immigrants are consumers of both bulk and private goods is also emerging as an aggregate demand augmenting factor (Addison and Worswick 2002). If the total supply increases more than the total demand, it is expected that the economy will have lower earnings and lower employment opportunities in the labor market, if the total demand arising as a result of migration flows exceeds the total supply, positive economic effects are expected.

In general, there are two main approaches to investigate the migration effect. The first of these is a spatial approach that changes, geographical clustering and local labor markets to determine the impact of migration on wages (Altonji and Card 1991; Card 1990, 2001, 2005; Dustmann et. al., 2005). This spatial approach assumes that cities or regions within a given country are separate labor market. Accordingly, they argue that immigrant movements have changed the wage structure of the local labor market (Kifle 2009). The idea is that immigrant flows, which increase the amount of labor in a particular group, will reduce wages in the local labor market. However, Card (1990, 2001, 2005) found that the US labor market had little impact on migration flows over natural income. Similarly, in his work on the British labor market, Dustmann et. al. (2005), in his work on New Zealand data, Maré and Stillman (2009) and using the Household Labor Force Survey (HLFS) data, Maani and Chen (2012) found little evidence that migration flows have negative effects on the employment of the local workforce.

The second approach is to demonstrate the impact of migration on different groups of labor market using national level data (Borjas 2003, 2004, 2005; Orrenius ve Zavodny 2007). Borjas (2003) describes both immigrants and pre-existing groups with both education and experience to assess the importance of both wage and wage-setting factors. Borjas (2003) shows that immigration is not constant in all groups. This heterogeneous source of migration creates enough variation to anticipate the impact of migrant entries on the economic consequences of pre-existing workers. However, studies using similar methodologies have been found to achieve different economic outcomes. D'Amuri et al. (2010) predicted the impact of migration flows on the German labor market in their study of Germany. According to the results of the research, Germany is the European country with the largest immigrant population. The authors also show that there is a perfect substitutional flexibility between immigrants and the local labor force. The effects of migration flows on different educational levels in the survey were also investigated and, according to the results obtained, migration flows cause a negative effect of around 1 percent in the highly educated group. On a less educated workforce it has been shown that immigration flows have a similar positive effect. Thus, the average impact of the migration on the German labor market is zero. Contrary to classical studies such as Borjas et. al. (1996), Ottoviano and Peri (2007) found that there is a complementary relationship between migrants and local labor force. In the study, immigrant movements generally reached a positive effect on wages in the local labor market.

\section{Method and Dataset}

Panel data analysis can be described as a method of predicting economic relations using horizon-slice series with time dimension in the most general sense. In this analysis, time series and cross section series are combined and a data set with both time and section size can be created. Panel data models have significant advantages over ordinary time series and/or cross-section models (Gujarati, 2003). In these models, the number of observations is larger than the cross-sectional and time series, and therefore the degree of freedom of the estimates of the parameters to 
be obtained is also increasing. Thus, the degree of the multiple linear link between the explanatory variables decreases and the efficiency and reliability of the econometric estimates increase. Moreover, the predicted models will be based on less restrictive assumptions. Panel data models allow the establishment and testing of more complex behavioral models than other methods. Another advantage of using panel data is; in contrast to estimations made by cross-sectional data where only the differences between units can be researched, it is possible to examine both units or differences within a unit according to time (Baltagi, 2005).

One of the simplest models used in panel data estimation is the Fixed Effect Model. In the Fixed Effect Model, the differences in the behavior of the units are trying to be revealed with the differences in the fixed term. However, it is assumed that the slope coefficients are constant. In this model, the fixed term is called the group-specific fixed term. As Greene (2003) points out, the constant qualification here implies that the coefficient can vary according to units, but is constant over time. It is assumed that the individual effects that are not observed in the Fixed Effect Model are related to the explanatory variables included in the model (Green, 2003: 285). For this reason, the differences between the units are modeled as parametric changes in the regression function. We can express the Fixed Effect Model as follows.

$$
\begin{aligned}
& y_{i t}=\bar{\beta}+\sigma_{i}+\beta_{2 i t} X_{2 i t}+\cdots+\beta_{\text {kit }} X_{\text {kit }}+\varepsilon_{\text {it }} \\
& \mathrm{i}=1,2 \ldots \ldots, \mathrm{Z} \text { ve } \mathrm{t}=1,2 \ldots \mathrm{n}
\end{aligned}
$$

In (1) equals, $\beta_{1 i}=\bar{\beta}_{1 i}+\alpha_{i}$ i'th stationary fixed term; $\bar{\beta}$ is the average fixed term shows. $\alpha_{i}$ represents the difference from the mean constant term for the i'th unit. If there is a relationship between the error in (1) equations and the explanatory variables, the Fixed Effect Model is considered as the appropriate model. Because in this case the Fixed Effect Model estimators are unbiased. Furthermore, if the number of $G$ is small and the number of observations ( $\mathrm{n}$ ) is large, the Fixed Effect Model is again the preferred model.

Unlike Fixed Effect Model, where the individual effects are not related to the explanatory variables involved in the model, it is more appropriate to assume that it is distributed randomly according to the units and to model accordingly (Green, 2003: 293). Thus, the constant term $\beta 1 \mathrm{i}$ in equation $\mathrm{x}$ is not constant, it will be a random variable with $\mathrm{x}$ average. In this case, the fixed term value for each unit is $\beta_{1 \mathrm{i}}=\beta+\mu_{\mathrm{i}} \cdot \mu_{\mathrm{i}}$ is the random error term with zero mean and constant variance. The Random Effect Model will be as follows.

$$
y_{i t}=\bar{\beta}+\beta_{2 i t} X_{2 i t}+\cdots+\beta_{\text {kit }} X_{\text {kit }}+\varepsilon_{\text {it }}+\mu_{i}
$$

or

$$
y_{i t}=\bar{\beta}+\beta_{2 i t} X_{i t}+\cdots+\beta_{\text {hit }} X_{\text {hit }}+u_{i}
$$

As can be seen, the error in $\left(u_{i}\right)$ is the compound error term and the components are the individual error term ( $\left.\mu_{i}\right)$ and the panel error term $\varepsilon_{i t}$. The basic assumptions of Random Effect Model are:

1. Both individuals-specific and panel error terms have a normal distribution. So,

$$
\varepsilon_{\mathrm{it}} \sim N\left(0, \sigma_{\varepsilon}^{2}\right) \text { and } \mu_{\mathrm{i}} \sim N\left(0, \sigma_{\mu}^{2}\right)
$$

2. Individual error terms are neither related to themselves nor to panel error. So,

$$
\begin{aligned}
& E\left(\mu_{i} \varepsilon_{i t}\right)=0 \\
& E\left(\mu_{i} \mu_{i}\right)=0(i \neq j) \\
& E\left(\varepsilon_{i t} \varepsilon_{i s}\right)=E\left(\varepsilon_{i t} \varepsilon_{i t}\right)=E\left(\varepsilon_{i t} \varepsilon_{i s}\right)=0(i \neq j ; t \neq s)
\end{aligned}
$$

The fundamental difference between Fixed Effect Model and Random Effect Model can be seen by comparing the equations (1) and (2). In the Fixed Effect Model, each section has its own distinct fixed term; In Random Effect Model, the constant term gives the average fixed term $(\bar{\beta})$ for all cross-sectional units, while the error term $\left(\mu_{i}\right)$ represents the random deviation of the constant term for each cross-sectional unit from this mean constant term. The effective prediction method used to predict Random Effect Model is the Generalized Least Squares (GLS) method. Random Effect Model provides more efficient estimates than the Fixed Effect Model if the number of sectional units in the panel data is large and the time period $(n)(G)$ is short. On the other hand, if $n$ is large and $G$ is small, then little difference is expected between the two estimation results and Fixed Effect Model is preferred as we mentioned earlier. However, if the number $\mathrm{n}$ is small and $\mathrm{G}$ is large, a significant difference is expected between the two estimation results. In this case, if the cross-sectional units are believed to be randomly drawn from the large sample, Random Effect Model is considered as a more appropriate model than Fixed Effect Model (Gujarati, 650-651).

The study aimed to investigate the effect of immigrants on the labor force participation rate of the local labor force has been examined by means of regression analysis, the dataset covering the period of 2011-2016 was used for 26 sub-regions of Turkey. From this point of view, factors affecting the labor market were considered separately 
as male, female and total labor force in this study and factors affecting the local labor market in study are covered in the following variables. All the data for the variables used in the study were obtained from the TUIK database. Table 1 shows dependent and independent variables used in the study.

\begin{tabular}{|l|l|l|}
\hline \multirow{4}{*}{$\begin{array}{l}\text { Independed } \\
\text { Variables }\end{array}$} & Name of Variables & Description \\
\cline { 2 - 3 } & ITM & Inflation rate in $i$ sub-region of Turkey in $t$ period (\%) \\
\cline { 2 - 3 } $\begin{array}{l}\text { Vepended } \\
\text { Variables }\end{array}$ & IM & $\begin{array}{l}\text { Total number of immigrants with working permission } i \text { sub-region of } \\
\text { Turkey in } t \text { period }\end{array}$ \\
\cline { 2 - 3 } & EX & Import amount in $i$ sub-region of Turkey in $t$ period (million dollar) \\
\cline { 2 - 3 } & LFPRF & $\begin{array}{l}\text { Export amount in } i \text { sub-region of Turkey in } t \text { period (million dollar) } \\
\text { period (\%) }\end{array}$ \\
\cline { 2 - 3 } & LFPRM & $\begin{array}{l}\text { Employment participations ratio of female labor force in } i \text { sub-region } \\
\text { of Turkey in } t \text { period (\%) }\end{array}$ \\
\hline
\end{tabular}

Table 1. Descriptions of Variables

The general form of the panel data regression models used in the study is; Employment participations ratio of total labor force (LFPRT)/ Employment participations ratio of female labor force (LFPRF)/ Employment participations ratio of male labor force (LFPRM), Inflation rate (I), Total number of immigrants with working permission (NTM), Import amount (IM) and Export amount (EX) as follows:

Model1: $\mathrm{LFPRM}_{\mathrm{it}}=\boldsymbol{\alpha}_{\mathbf{0}}+\boldsymbol{\alpha}_{1} \mathrm{I}_{\mathrm{it}}+\boldsymbol{\alpha}_{2} \mathrm{NTM}_{\mathrm{it}}+\boldsymbol{\alpha}_{3} \mathrm{IM}_{\mathrm{it}}+\boldsymbol{\alpha}_{4} \mathrm{EX}_{\mathrm{it}}+\varepsilon_{\mathrm{it}}$

Model2: $\mathrm{LFPRF}_{\mathrm{it}}=\boldsymbol{\alpha}_{\mathbf{0}}+\boldsymbol{\alpha}_{1} \mathrm{I}_{\mathrm{it}}+\boldsymbol{\alpha}_{2} \mathrm{NTM}_{\mathrm{it}}+\boldsymbol{\alpha}_{3} \mathrm{IM}_{\mathrm{it}}+\boldsymbol{\alpha}_{4} \mathrm{EX}_{\mathrm{it}}+\varepsilon_{\mathrm{it}}$

Model3: LFPRT $_{\text {it }}=\boldsymbol{\alpha}_{\mathbf{0}}+\boldsymbol{\alpha}_{1} \mathrm{I}_{\mathrm{it}}+\boldsymbol{\alpha}_{2} \mathrm{NTM}_{\mathrm{it}}+\boldsymbol{\alpha}_{3} \mathrm{IM}_{\mathrm{it}}+\boldsymbol{\alpha}_{4} \mathrm{EX}_{\mathrm{it}}+\varepsilon_{\mathrm{it}}$

In models, $\boldsymbol{\alpha}_{1}, \boldsymbol{\alpha}_{2}, \boldsymbol{\alpha}_{3}$ and $\boldsymbol{\alpha}_{4}$, independent variable coefficients; $i$ each sub-region; $t$ showed the time. Finally, $\varepsilon_{i t}$ is the error term.

\section{Empirical Results}

In this study, where the effects of migrants with work permits in Turkey on the local labor force were searched, three different models were developed to examine these effects. The first model seeks to investigate the impact of migrant workers with work permits on the labor force participation rate of local male labor force, while the second examines the impact of immigrants with work permits on the labor force participation rate of the local female labor force. The third and final model, the impact on total labor force participation rate of immigrants with a work permit in Turkey was created to demonstrate. In addition to the total number of migrants who have work permits in the models created, inflation rate, imports and exports, which are among the factors affecting labor participation rates in the literature, have also been added to the models. The results of both the fixed effect and the random effect model are estimated by the panel regression method and the obtained estimation results are shown in Table 2 . 


\begin{tabular}{|c|c|c|c|c|c|c|}
\hline & \multicolumn{2}{|c|}{ Model 1} & \multicolumn{2}{|c|}{ Model 2} & \multicolumn{2}{|c|}{ Model 3} \\
\hline Variables & $\begin{array}{l}\text { Fixed Effect } \\
\text { (1) }\end{array}$ & $\begin{array}{c}\text { Random Effect } \\
\text { (2) }\end{array}$ & $\begin{array}{c}\text { Fixed Effect } \\
\text { (3) }\end{array}$ & $\begin{array}{c}\text { Random Effect } \\
\text { (4) }\end{array}$ & $\begin{array}{c}\text { Fixed Effect } \\
\text { (5) }\end{array}$ & $\begin{array}{c}\text { RandomEffect } \\
\text { (6) }\end{array}$ \\
\hline I & $\begin{array}{l}3.57372^{* *} \\
(1.49281)\end{array}$ & $\begin{array}{c}2.95452^{* *} \\
(1.512)\end{array}$ & $\begin{array}{c}1.570561 \\
(1.826669)\end{array}$ & $\begin{array}{c}1.405176 \\
(1.816542)\end{array}$ & $\begin{array}{l}5^{5.144288}{ }^{*} \\
(2.991719\end{array}$ & $\begin{array}{c}4.520137 \\
(2.995905)\end{array}$ \\
\hline NTM & $\begin{array}{l}0.000109 \\
(0.00010)\end{array}$ & $\begin{array}{l}0.000073 \\
(0.00009)\end{array}$ & $\begin{array}{l}0.00040^{* * * *} \\
(0.000124)\end{array}$ & $\begin{array}{l}0.000400^{* * * *} \\
(0.0001204)\end{array}$ & $\begin{array}{c}0.000513^{* *} \\
(0.0002041)\end{array}$ & $\begin{array}{c}0.000483^{* *} \\
(0.0001948)\end{array}$ \\
\hline IM & $\begin{array}{l}-0.449424 \\
(0.99779)\end{array}$ & $\begin{array}{l}-0.1624322 \\
(0.567624)\end{array}$ & $\begin{array}{l}-1.472882 \\
(1.220937)\end{array}$ & $\begin{array}{l}-0.7015207 \\
(0.9302069)\end{array}$ & $\begin{array}{l}-1.922302 \\
(1.999652)\end{array}$ & $\begin{array}{l}-1.035705 \\
(1.407596)\end{array}$ \\
\hline $\mathbf{E X}$ & $\begin{array}{l}2.5783^{* * *} \\
(0.98489)\end{array}$ & $\begin{array}{c}0.3750723 \\
(0.64561)\end{array}$ & $\begin{array}{l}0.7400399 \\
(1.205159)\end{array}$ & $\begin{array}{c}0.251625 \\
(1.015259)\end{array}$ & $\begin{array}{l}3.318419^{*} \\
(1.97381)\end{array}$ & $\begin{array}{c}1.082885 \\
(1.566612)\end{array}$ \\
\hline Constant & $\begin{array}{l}17.77723 \\
(25.3888)\end{array}$ & $\begin{array}{c}58.78738^{* * *} \\
(7.58701)\end{array}$ & $\begin{array}{c}43.32228 \\
(31.06686)\end{array}$ & $\begin{array}{l}\text { 38.03578 }^{\text {** }} \\
(17.11486)\end{array}$ & $\begin{array}{l}61.09946 \\
(50.8813)\end{array}$ & $\begin{array}{l}90.23159^{* * *} \\
(23.01896)\end{array}$ \\
\hline Period & $2011-2016$ & $2011-2016$ & $2011-2016$ & 2011-2016 & 2011-2016 & 2011-2016 \\
\hline Region & 26 & 26 & 26 & 26 & 26 & 26 \\
\hline $\begin{array}{lr}\text { Wald } & \text { chi- } \\
\text { square, } & \text { p } \\
\text { value } & \end{array}$ & & 0.0275 & & 0.0169 & & 0.0605 \\
\hline $\begin{array}{l}\text { F-Test, } \\
\text { p value }\end{array}$ & 0.0191 & & 0.0131 & & 0.0201 & \\
\hline Observations & 156 & 156 & 156 & 156 & 156 & 156 \\
\hline
\end{tabular}

Tablo 2. Panel Veri Regresyon Tahminleri

According to the estimated results in Table 2, the immigrants who have permission to work in Turkey have a statistically significant and positive effect on the employment participation rate of the total labor force participation rate and employment participation rate of female labor force, while there is no statistically significant impact on the employment participation rate of male in the labor force. These results are valid for both the fixed effect model and the random effect model. From these results, it can be said that there is a complementary relationship between immigrants who have permission to work in Turkey and local female labor force. Other variables used in the research have been found out that the inflation rates have a statistically significant and positive effect on the employment participation rates of the local male labor force and there is no statistically significant effect on the employment participation rates of the local female labor force. Similarly, it was found that exports have a statistically significant and positive effect on the employment participation rate of the local male workforce and no statistically significant effect on the employment participation rate of the local female labor force. There is no statistically significant impact on imports, neither on the employment participation rate of the local male labor force nor on the employment participation rate of the local female labor force.

\section{Discussion}

The technological developments and the results of these developments have allowed the production factors to move without limit. This situation reveals both the favorable and the unfavorable results of the countries. As a matter of fact, the labor is moving the sedan to get to the frontier. The resulting situations are a good example of this. Immigrants, while being dependent on the social and economic structure of the receiving countries, sometimes have a positive effect on the labor market of the receiving countries, but sometimes this is the opposite. In this sense, Turkey has emerged as a country which has a lot of immigrants, especially in the last period in parallel with the developments in its surroundings. And as a consequence of this situation, the influences of immigrants on the local labor market are an important debate in both academic and political circles. In this respect, the study results show that while immigrants who are allowed to work have no influence on the employment participation rate of male local labor force, immigrants who are allowed to work have a positive effect on the employment participation rate of female local labor force working participation. According to these results, migrants allowed to work in Turkey have a positive effect on the participation rate even if just a bit. From a gender perspective, it has been found that immigrants have positive effects on female labor force participation rates. But, there has been no significant impact on the male labor force participation rate of migrants. So that, it can be said that immigrants who are allowed to work in Turkey have created new job opportunities in the sectors which increase female's participation on the employment. 


\section{References}

- Addison T, Worswick C (2002) The impact of immigration on the earnings of natives: evidence from Australian micro data. The Economic Record 78(1):68-78.

- Altonji, J. G. and D. Card (1991). The Effects of Immigration on the Labor Market Outcomes of Lessskilled Natives. In J. M. Abowd and R. B. Freeman (Eds.), Immigration, Trade, and the Labor Market, Chapter 7, pp. 201-234. Chicago: University of Chicago Press.

- Baltagi, B. H. (2005). Econometric Analysis of Panel Data. John Wiley Sons.

- Borjas G. J. (2003a) The labour demand curve is downwards sloping: re-examining the impact of immigration on the labor market. Q J Econ 118(4):1335-1374.

- Borjas G. J. (2004) Increasing the supply of labor through immigration: measuring the impact on nativeborn workers. Centre for Immigration Studies.

- Borjas G. J. (2005) The labor-market impact of high-skill immigration. Am Econ Rev 95(2):56-60.

- Borjas G. J., Freeman RB, Katz L (1996) Searching for the effect of immigration on the labor market. Am Econ Rev 86(2):246-251.

- Borjas G. J., Grogger J, Hanson GH (2008) Imperfect substitution between immigrants and natives: a reappraisal. NBER Working Paper No. 13887.

- Borjas, G. J. (1999). "The economic analysis of immigration”, Chapter 28, Handbook of Labor Economics, vol. 3, pp. 1697-760.

- Borjas, G. J. (2003b) The Labor Demand Curve is Downward Sloping: Reexamining the Impact of Immigration on the Labor Market. Quarterly Journal of Economics 118 (4), 1335-1374.

- Breusch T. and Pagan A. 1980. "The Lagrange Multiplier Test and Its Applications to Model Specification in Econometrics". The Review of Economic Studies, 47, pp. 1287-1294.

- Card D (1990) The impact of the mariel boatlift on the Miami labor market. Ind Lab Relat Rev 43(2):245257.

- Card D (2001) Immigrant inflows, native outflows, and the local market impacts of higher immigration. J Labor Econ 19(1):22-64.

- Card D (2005) Is the new immigration really so bad? Econ J 115(507):F300-F323.

- Chiswick, B.R. (1993). "Review Of İmmigration And And The Work Force: Economic Consequences For The United States And Source Areas, Journal Of Economic Literature, vol. 31, pp. 910-1.

- Choi, In (2001), “Unit Roots Tests for Panel Data.” Journal of International Money and Finance, 20: 229272.

- Christian Dustmann, Albrecht Glitz, Tommaso Frattini (2008). “The Labour Market Impact of Immigration”, Oxf Rev Econ Policy, 24 (3): 477-494. doi: 10.1093/oxrep/grn024.

- D'Amuri F, Ottaviano GI. Peri G (2010) The labor market impact of immigration in Western Germany in the 1990s. Eur Econ Rev 54(4):550-570.

- Dustman C, Glitz A, Tommaso F (2008) The labour market impact of immigration. Oxford Rev Econ Pol 24(3):477-494.

- Dustmann C, Fabbri F, Preston I (2005) The impact of immigration on the British labour market. Econ J 115(507):F324-341.

- Eckstein, Z. and Y. Weiss (2004). On the Wage Growth of Immigrants: Israel, 1990-2000. Journal of the European Economic Association 2 (4), 665-695.

- Edin, P.-A., P. Fredriksson, and O. Aslund (2003). Ethnic Enclaves and the Economic Success of Immigrants- Evidence from a Natural Experiment. Quarterly Journal of

- Ethier, W. J. (1984). Protection and Real Incomes Once Again. Quarterly Journal of Economics 99 (1), 193 200.

- Filer, R. K. (1992). The Effect of Immigrant Arrivals on Migratory Patterns of Native Workers. In G. J. Borjas and R. B. Freeman (Eds.), Immigration and the Work Force: Economic Consequences for the United States and Source Areas, Chapter 8, pp. 245-269. Chicago: University of Chicago Press.

- Frees, E.W. (1995), “Assessing Cross-Sectional Correlation in Panel Data”, Journal of Econometrics 69:393, 414-496.

- Frees, E.W. (2004), Longitudinal and Panel Data: Analysis and Applications in the Social Sciences, Cambridge: Cambridge University Press. 
- $\quad$ Friedberg, R.M. and Hunt, J. (1995). "The Impact of Immigration on Host Country Wages, Employment And Growth, Journal of Economic Perspectives, vol. 9, pp. 23-44.

- Friedman, M. (1937), "The use of ranks to avoid the assumption of normality implicit in the analysis of variance", Journal of the American Statistical Association, 32: 675-701.

- Greene, W. H. (2003). Econometric Analysis, Prentice Hall, Fifth Edition, ABD.

- Grossman, J. B. (1982). The Substitutability of Natives and Immigrants in Production. Review of Economics and Statistics 64 (4), 596-603.

- Gujarati, D. (2003). Basic Econometrics, McGraw Hill, Fourth Edition, ABD.

- Hoyos, R. E. D. and Sarafidis, V. (2006). 'Testing for Cross-Sectional Dependence in Panel Data Models'. The Stata Journal, 6(4), pp. 482-496.

- $\quad$ Kifle T (2009) The effect of immigration on the earnings of native-born workers: evidence from Australia. J Socio-Econ 38(2):350-356.

- Maani SA, Chen Y (2012) Effects of a high-skilled immigration policy and immigrant occupational attainment on domestic wages. Australian J Lab Econ 15(2):101-121.

- Manacorda, M., A. Manning, and J. Wadsworth (2006). The Impact of Immigration on the Structure of Male Wages: Theory and Evidence from Britain. CReAM Discussion Paper No.08/06.

- Maré DC, Stillman S (2009) The impact of immigration on the labour market outcomes of New Zealanders. Motu Economic and Public Policy Research: Motu Working Paper 09-11.

- Mishra P (2007) Emigration and wages in source countries: evidence from Mexico. J Devel Econ 82(1):180199.

- Orrenius PM, Zavodny M (2007) Does immigration affect wages? A look at occupation-level evidence. J Lab Econ 14(5):757-773.

- Ottaviano, G. and G. Peri (2006). Rethinking the Effects of Immigration on Wages. NBER Working Paper No. 12497.

- Ottaviano, G. and G.Peri (2007) Rethinking the effects of immigration on wages. Memeo, UC Davis. 